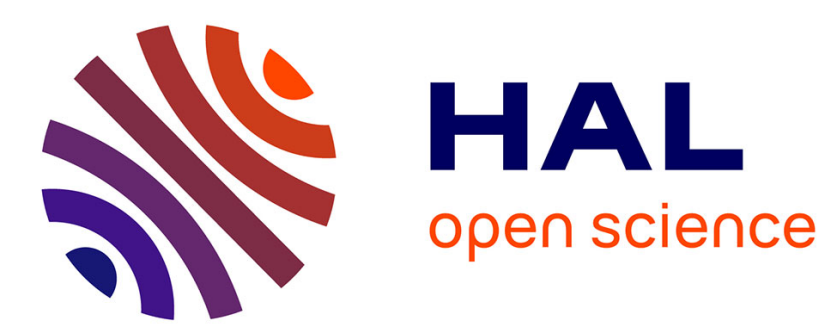

\title{
Prospective methods for human papillomavirus detection by fluorescent in situ hybridization and laser excitation
}

\author{
G. Lizard, C. Souchier, Y. Chardonnet
}

\section{To cite this version:}

G. Lizard, C. Souchier, Y. Chardonnet. Prospective methods for human papillomavirus detection by fluorescent in situ hybridization and laser excitation. Journal de Physique IV Proceedings, 1994, 04 (C4), pp.C4-257-C4-260. 10.1051/jp4:1994459 . jpa-00252722

\section{HAL Id: jpa-00252722 https://hal.science/jpa-00252722}

Submitted on 1 Jan 1994

HAL is a multi-disciplinary open access archive for the deposit and dissemination of scientific research documents, whether they are published or not. The documents may come from teaching and research institutions in France or abroad, or from public or private research centers.
L'archive ouverte pluridisciplinaire HAL, est destinée au dépôt et à la diffusion de documents scientifiques de niveau recherche, publiés ou non, émanant des établissements d'enseignement et de recherche français ou étrangers, des laboratoires publics ou privés. 


\title{
Prospective methods for human papillomavirus detection by fluorescent in situ hybridization and laser excitation
}

\author{
G. LIZARD, C. SOUCHIER* and Y. CHARDONNET**
}

Centre Commun de Cytométrie en Flux, INSERM U-80, Hopital Edouard Herriot, Lyon, France

${ }^{*}$ Cytologie Analytique, Université Lyon I, Lyon, France

** INSERM U346, Affiliée CNRS, Hopital Edouard Herriot, Lyon, France

\section{ABSTRACT}

As some human papillomaviruses (HPV) have an oncogenic potential, it is of interest to develop cytological methods which allow the detection of low copy numbers of HPV DNA. The human uterine carcinoma cell lines CaSki, SiHa and HeLa were used since they contain different copy numbers of HPV DNA per cell: 500-600 copies of HPV16, 1-2 copies of HPV 16 and 20-50 copies of HPV18, respectively. HPV DNA was revealed by fluorescent in situ hybridization (FISH) with biotinylated probes. The sensitivity of detection of viral DNA depends not only on the FISH reaction conditions but also on some characteristics of the flow cytometer (FC). By flow cytometry (FCM), the detection of viral DNA by FISH was limited to 500-600 copies per cell. The fluorescence signal was multiplied by a factor of 3 after successive fixations in $4 \%$ paraformaldehyde and $70 \%$ ethanol as compared to fixation in $70 \%$ ethanol. It was also enhanced after in situ amplification with polymerase chain reaction (PCR) so that 50 copies of HPV 18 were detected in HeLa cells. The choice of FC was important since a stronger signal was obtained on FACScan than on FACStar plus. Furthermore, closed flow chamber gave better results than nozzle with jet in air. The detection of 1-2 copies of HPV DNA type 16 in SiHa cells was possible with laser scanning confocal microscopy (LSCM) without in situ PCR. Thus, LSCM may be more adapted than FCM to detect low copy numbers of HPV DNA.

\section{INTRODUCTION}

The detection of nucleic acid sequences by in situ hybridization has many applications in molecular and clinical pathology. Among these, are investigations on interphasic cells to identify and characterize malignant or infected cells. The development of fluorescent in situ hybridization (FISH) allows the detection of DNA sequences as small as 2 to $6 \mathrm{~kb}(1)$; the use of fluorescent markers permits simultaneous investigations of various nucleic acid sequences (2). Association of FISH with FCM allows analyses of a hundred cells per second and detection of low percentages of cells containing specific DNA sequences (3). The detection of nucleic acid sequences in whole cells by FCM is linked to the sensitivity of the flow cytometer (FC) since the fluorescence intensity of hybridization spots is often low and the fluorescence background high. For the detection of low quantities of nucleic acid sequences by FISH and FCM the fluorescent signals may be increased by genomic amplification (3) of the target sequences by a polymerase chain reaction (PCR) and optimization of the performances of FC. The human uterine carcinoma CaSki, SiHa and HeLa cells 
were used as model to detect by FCM low copy numbers of HPV in whole cells; HPV DNA was revealed by FISH preceded or not by PCR. The sensitivity for detection of HPV DNA by FCM waS compared to that of laser scanning confocal microscopy (LSCM).

\section{MATERIALS AND METHODS}

Fluorescence in situ hybridization (FISH) was performed on Caski, SiHa and HeLa cell suspensions as previously described (4), using cloned HPV DNA type 16 and 18 biotinylated with 11-dUTP. For LSCM, deposits of 40000 cells were applied to glass slides and mounted in PBS-glycerol (1:9 v/v) containing $0.5 \mu \mathrm{g} / \mathrm{ml}$ propidium iodide to counterstain cell nuclei and $2.3 \%(\mathrm{w} / \mathrm{v})$ 1,4-diazobicyclo$(2,2,2)$-octane (DABCO) as an anti-fading.

In situ genomic amplification was performed by PCR derived from Haase et al (5) and Nuovo et al (6). Briefly, the cells resuspended in PBS were fixed in $4 \%$ paraformaldehyde and in $70 \%$ ethanol, they were successively treated with $0.2 \mathrm{~N} \mathrm{HCl}, 0.5 \mu \mathrm{g} / \mathrm{ml}$ of proteinase $\mathrm{K}$ and heated at $50^{\circ} \mathrm{C}$, before exposure to amplification mixture. The primers used were chosen in the E6-E7 region of HPV types 16 and 18 (7). Amplification was performed on a DNA thermal cycler (Perkin Elmer) with 20 cycles $\left(94^{\circ} \mathrm{C}\right.$ for $1 \mathrm{~min}, 55^{\circ} \mathrm{C}$ for $2 \mathrm{~min}$ and $72^{\circ} \mathrm{C}$ for $\left.3 \mathrm{~min}\right)$. Hybridization was carried out overnight with the biotinylated plasmid probes and DNA-DNA hybrids were revealed by a three step reaction (4).

Flow cytometry analyses were performed on a FACScan and a FACStar Plus flow cytometers (Becton Dickinson). On FACScan, the excitation source was an air cooled argon ion laser emitting a $488 \mathrm{~nm}$ beam at $15 \mathrm{~mW}$. The flow chamber was a rectangular closed flow chamber constituted by a nozzle which leads into a tube with a cross section of $430 \times 180 \mu \mathrm{m}$ and the sample was delivered at $12 \mu \mathrm{l} /$ min. A microscope objective with $\mathrm{NA}=1.2$ was used to collect fluorescence and the transmittance through the lens was $80 \%$ from 400 to $650 \mathrm{~nm}$. On FACStar Plus, the excitation source was a water cooled argon ion laser (Spectra Physics) adjusted to emit a $488 \mathrm{~nm}$ beam at $250 \mathrm{~mW}$; the flow chamber was a nozzle with jet in air (diameter $76 \mu \mathrm{m}$ ), the sample delivery was adjusted at its minimum value, $18 \mu \mathrm{l} / \mathrm{min}$, but the flow velocity was 100 times higher than on FACScan. Fiuorescence was collected with a microscope objective with $N A=0.6$ and the transmittance through the lens was around 50\%. Green fluorescence of fluorescein ( $\lambda$ Ex Max: $494 \mathrm{~nm} ; \lambda \mathrm{Em}$ Max: $517 \mathrm{~nm}$ ) was collected through a $530 / 30 \mathrm{~nm}$ band pass filter and measured on a scale of 4 decades of log. The data were analysed with the software LYSYS II (Becton Dickinson). Detection of a minimal number of fluorescent molecules depends of the performance of $F C(8)$. The fluorescence signal $\left(n_{f}\right)$ obtained by FCM is defined by Equ(1):

$$
n_{f}=\text { const. } f(N A)^{2} T v^{-1} i_{x} \int \varepsilon(\lambda) I_{X}(\lambda) d(\lambda) \text {. }
$$

where $f$ is the number of fluorescent molecules per cell; NA the numerical aperture of the objective used to collect fluorescence; $T$ the transmission of fitters and other components in the detection light pass; $v$ the flow velocity; the integral is the overlap between the fluorescence excitation spectrum, $\varepsilon(\lambda)$ , of the dye and the spectrum of the excitation light, $I_{x}(\lambda) ; i_{x}$ is the value of the excitation intensity. The value of the constant is: const $=\left((f+b) /\left(\Phi_{e} a f^{2}\right)\right) ; b$ is the background constant; $a$ is a constant function of the overlap between the fluorescence excitation spectrum of the dye and the spectrum of excitation light and various characteristics of the flow cytometer; $\Phi$ e the photoelectron 
quantum efficiency, is the probability that a photon which reaches the photocathode of the detector will release an electron.

Microscope examination:-Digital images of LSCM were collected with a Zeiss confocal laser microscope (Model LSCM10). The objective magnification was 63-fold with a 1.4 numerical aperture Plan Apochromatic oil immersion objective. Fluorescein and propidium iodide $(\lambda E x$ Max: $536 \mathrm{~nm} ; \lambda \mathrm{Em}$ Max: $623 \mathrm{~nm}$ ) were excited at $488 \mathrm{~nm}$ with an air-cooled argon laser. The laser beam was attenuated with an F1 neutral density filter (10\% transmission). The green fluorescence was collected through a $530 / 15 \mathrm{~nm}$ band pass filter and the red fluorescence through a $590 \mathrm{~nm}$ long pass filter. Images were averaged during image aquisition for each pixel, line by line with the function "Fast frame averaging".

\section{RESULTS}

With FCM, HPV DNA sequences were detected by FISH only in CaSki cells with an amplified immunological method involving a rabbit anti-biotin antiserum, a biotinylated anti rabbit anti-serum and streptavidin fluorescein. The signal was stronger by a factor of 3 in cells fixed in $4 \%$ paratormaidehyde and $70 \%$ ethanol as compared to fixation in $70 \%$ ethanol. The number of molecules of fluorescein per cell was enhanced by in situ genomic amplification which led to detection of HPV DNA in HeLa cells containing 20-50 copies of HPV DNA type 18. The fluorescence signal depends not only on FISH reaction conditions but also on the choice of $\mathrm{FC}$. The intensity of the signals was higher on FACScan than on FACStar Plus. This is in agreement with Equ(1) since NA and transmittance of the microscope objective were higher on FACScan than on FACStar Plus and flow velocity (v) on FACStar Plus was 100 times higher than on FACScan. However, excitation intensity (ix) was higher on FACStar Plus (FACStar plus : $i_{x}=250 \mathrm{~mW}$; FACScan : $i_{x}=15 \mathrm{~mW}$ ). Meanwhile, since fluorescence background increases with excitation intensity, the background was higher on the FACStar Plus and the signal to noise ratio decreased. For a given FC, fluorescence intensity depends on the value of "const" which depends on the parameters b, a and $\Phi$. Thus, the value of "const" may also modulate fluorescence intensity from one flow cytometer to another but this parameter was not taken into consideration. As in Equ(1), the fluorescence intensity is related to the number of fluorescent molecules $(\mathfrak{f})$ per cell, it is necessary to obtain the highest fluorescence signal. By LSCM , without anti-fading, it was possible to detect and localize hybridization spots in the nuclei of CaSki and HeLa cells counterstained with propidium iodide. With an anti-fading, DABCO, 1-2 copies of HPV DNA were detected in SiHa cells. Data obtained are summarized in table 1.

Table 1:Limit of detection of HPV DNA on whole cells by flow cytometry and LSCM.

\begin{tabular}{llccc}
\hline $\begin{array}{l}\text { Method of } \\
\text { analysis }\end{array}$ & $\begin{array}{l}\text { Detection of } \\
\text { HPV DNA }\end{array}$ & $\begin{array}{c}500-600 \text { copies } \\
\text { of HPV DNA }\end{array}$ & $\begin{array}{c}20-50 \text { copies } \\
\text { of HPV DNA }\end{array}$ & $\begin{array}{c}1-2 \text { copies } \\
\text { of HPV DNA }\end{array}$ \\
\hline Flow cytometry & FISH & + & - & - \\
& PCR+FISH & + & + & - \\
\hline LSCM & FISH & + & + & + \\
& FISH + antifading & + & + & + \\
\hline
\end{tabular}




\section{DISCUSSION}

We have shown that in FCM the fluorescence signal depends on FISH reaction conditions such as cell fixation, and that it was enhanced by genomic amplification. The interest of FCM is to analyze individual cells, to detect nucleic acid sequences in a small proportion of abnormal cells in cancerology or infectious diseases. However, spontaneous fluorescence of cells leads to a high fluorescence background which prevents detection of a few nucleic acid molecules producing a low fluorescence signal. Fluorescence detectable by FCM depends on several parameters of FC comprised in Equ(1). A better detection of a few molecules of dyes may be obtained by optical characteristics : the microscope objective used to collect fluorescence, the optical filters and the photomultipliers; NA of the collecting lens must be low and the transmittance of the lens and optical filters high. Photomultipliers must have low noise and give a signal for low quantities of photons reaching the photocathode. Improvement of fluid characteristics is also a simple and efficient method to reduce the limit of DNA detection. The decrease of flow velocity increases the sensitivity and closed flow chambers have a higher performance than nozzles with jet in air (8). According to Equ(1), a high intensity of the excitation source would also enhance the fluorescence of the signal, however, since the background concomitantly increases with the intensity of excitation, the ratio signal to noise decreases. Thus, reducing background is of interest. Since the threshold for the signal required to trigger the gate pulse is adjustable, it can be set so that background noise and signal from irrelevant particles, such as debris, are not measured.

The better sensitivity of LSCM as compared to FCM is essentially due to the optical characteristics of the microscope which eliminate out of focus fluorescence (9), and thus, permits detection of small hybridization spots. LSCM remains however difficult to use routinely

\section{ACKNOWLEDGEMENTS}

The authors thank G Orth, Paris and H Zur Hausen, Heidelberg for giving HPV 16 and 18 plasmids, $\mathrm{J}$ Carew, for reviewing the English of this manuscript, and MC Chignol for her technical assistance.

\section{REFERENCES:}

(1)- Viegas-Pequignot E, Dutrillaux B, Magdelenat H et al. Proc Natl Acad Sci USA 86 (1989) 582.

(2)- Nederlof PM, Van der Flier S, Wiegant J et al. Cytometry 11 (1990) 126.

(3)-Patterson BK, Till M, Otto P et al. Science 260 (1993) 976.

(4)-Lizard G, Chignol MC, Chardonnet $Y$ et al. J Immunol Methods 157 (1993) 31.

(5)-Haase AT, Retzel EF, Staskus KA. Proc Natl Acad Sci USA 87 (1990) 4971.

(6)-Nuovo G, MacConnel P, Forde A, Delvenne P. Am J Pathol 139 (1991) 847.

(7)-Soler C, Allibert $P$, Chardonnet $Y$ et al. J Virol Methods 35 (1991) 143.

(8)- Steen HB. Cytometry 13 (1992) 822.

(9)-Brakenhoff GJ, Blom P, Barends P. J Microsc 117 (1979) 219. 